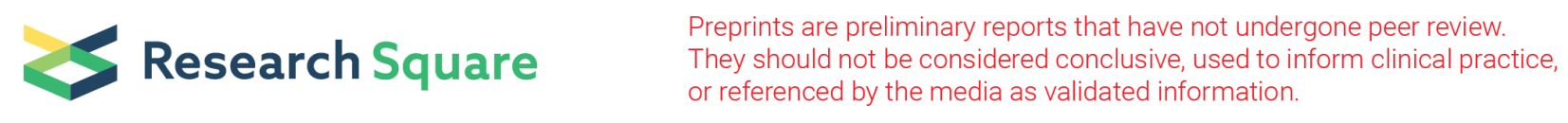

\title{
Oral Allergy Syndrome Caused By Japanese Radish: A Case Report
}

Atsushi Uesugi ( $\nabla$ uesugi.atsushi@tokushima-u.ac.jp )

Tokyo Medical and Dental University https://orcid.org/0000-0002-0496-8591

Fumihiko Tsushima

Tokyo Medical and Dental University

Youji Miyamoto

Tokushima University Graduate School

Hiroyuki Harada

Tokyo Medical and Dental University

\section{Case report}

Keywords: Oral Allergy Syndrome, food allergy, herpetic gingivostomatitis, Japanese radish, skin prick test

Posted Date: December 17th, 2021

DOI: https://doi.org/10.21203/rs.3.rs-1043597/v2

License: (c) (1) This work is licensed under a Creative Commons Attribution 4.0 International License. Read Full License 


\section{Abstract}

Background: Oral allergy syndrome (OAS) is a type of food allergy that manifests as hypersensitivity symptoms of the oropharyngeal mucosa on ingestion of specific foods with oral findings resembling herpetic gingivostomatitis. Symptoms can also appear in parts other than the oral cavity. There are a few reports of OAS caused by consuming radishes in the literature.

Case presentation: A 31-year-old male presented to our department with stomatitis and pharyngeal pain. The patient did not have a history of allergy, and herpetic gingivostomatitis was suspected. He was admitted to the emergency room of our hospital after complaining of oral and epigastric pain a few days later. On admission, symptoms noted were similar to those when he first visited our department. After detailed history taking, he reported consuming raw Japanese radish frequently, which gave rise to his symptoms. Radish was strongly suspected as the causative allergen. The skin prick test result was positive, confirming the diagnosis of OAS.

Conclusions: OAS can be diagnosed easily once the food causing symptoms is identified. However, guiding the diagnosis can be challenging if the patient is unaware of food allergies. Upon encountering widespread erosion in the oral cavity, it is essential to consider OAS as the possible cause.

\section{Background}

Oral allergy syndrome (OAS) is a type of food allergy that manifests as hypersensitivity symptoms of the oropharyngeal mucosa after ingesting specific foods such as fruits and vegetables [1]. The symptoms appear similar to those of herpetic gingivostomatitis, and guiding diagnosis can be challenging unless the patient is aware of food allergies. Furthermore, these symptoms can also appear in parts other than the oral cavity. We present a case of OAS caused by consuming raw Japanese radish.

\section{Case Presentation}

A 31-year-old male presented to our department in October 2019 with stomatitis and pharyngeal pain. The patient reported having a fever of $38{ }^{\circ} \mathrm{C}$, general malaise, epigastric pain, and pain in the oral cavity a few days earlier. There was a history of reflux esophagitis and hemorrhoids but no history of allergy. Before the patient's visit, general malaise and epigastric pain had improved. Minor aphthae were observed in the soft palate and mandibular gingiva; the hard palate had slightly eroded (Figure 1). Herpetic gingivostomatitis was suspected based on findings of the oral mucosa. C-reactive protein was slightly elevated at $2.96 \mathrm{mg} / \mathrm{dL}$. The total leukocyte count was $8,390 \mathrm{cells} / \mu \mathrm{L}$ (normal: $4500-11000 / \mu \mathrm{L}$ ). The herpes simplex virus IgG antibody titer was positive (44.2 times the normal value). IgM antibody titer was less than 0.80 , which was negative. The stomatitis showed improvement, and the patient was instructed to gargle with azulene sodium sulfonate. The stomatitis and pharyngeal pain improved almost entirely after a week. However, 3 weeks after the first visit, the patient was admitted to the emergency room of our hospital with severe epigastric and oral pain. The patient's symptoms were identical to those from his first visit. Upon detailed history taking, the patient mentioned eating raw grated Japanese radish frequently. After suspecting allergy to Japanese radish, an antihistamine was administered. Interestingly, allergic symptoms did not appear when eating cooked Japanese radish.

We suspected OAS and Japanese radish as the allergen. A skin prick test and oral challenge test were performed at the dermatology department. The radioimmunosorbent test (RIST) and the radioallergosorbent test (RAST) showed negative results (Table 1). A skin prick test using grated raw radish and non-grated raw radish found the former as an allergen, while the latter tested negative. Considering the risk of anaphylactic shock, radish was not used for the oral challenge. Instead, mustard and wasabi, which belong to the same Brassica family, were used. When an oral challenge test was performed using mustard and wasabi, the patient experienced a tingling sensation in the palate immediately after ingestion, and the mucous membrane showed reddening (Figure 2).

After eating raw Japanese radish, the patient experienced in the oral cavity and pharynx, and the skin prick test result was positive; consequently, we diagnosed the patient with OAS caused by Japanese radish. We recommended the patient to limit the intake of foods belonging to the Brassica family, including radish. An antihistaminic drug and injectable epinephrine were prescribed as a precaution in the case of an accidental onset.

\section{Discussion And Conclusions}

In 1987, Amlot et al. proposed OAS as a phenomenon in which allergic symptoms may appear in the oral mucosa and may spread to the whole body after ingesting food positive on the skin prick test [1].

OAS is a relatively new concept in food allergies. Food allergies are thought to have the same sensitizers and inducers as those of other allergies. However, in recent years, food allergies have exhibited cross-reactivity toward the pollen antigen owing to differences between sensitizers and inducers.

Food allergens that cause conventional intestinal sensitization are termed class I food allergens, and those proteins in fruits and vegetables causing allergy owing to cross-reactivity with the pollen antigen are termed class $\nabla$ food allergens [2]. Class I food allergens are resistant to heat and digestive enzymes; thus, the symptoms appear systemically. Class II antigens are not resistant to heat and digestive enzymes; thus, their symptoms 
are often localized to the oropharynx. OAS is a class II food allergy. Most sensitizers causing OAS include pollen and latex, with many of these agents being key components of food. OAS is a new concept in food allergy and is classified as a special type of immediate allergy [3]. Being a new class, there are no unified diagnostic criteria for OAS.

The diagnostic criteria for OAS proposed by Muluk and Cingi are based on history taking and positive skin prick test result triggered by fresh food extract [4]. Oral challenge results are normally positive for raw food and negative for the cooked version of the same food item. In our case, oral lesions and positive skin prick test results were present and conformed to the aforementioned diagnostic criteria for OAS; thus, a definitive diagnosis of OAS caused by Japanese radish was made.

Since 1974, a total of eight cases of radish allergy have been reported in the literature, including this case (Table 2) [5-11]. Oral mucositis was observed in three cases, and oral cavity involvement was not mentioned in five other cases. Despite this being a food allergy, there appears to be a little interest in studying the changes occurring in the oral cavity. According to the diagnostic criteria proposed by Muluk and Cingi [4], only cases 7 and 8 (this case) were diagnosed with radish-induced OAS. In addition, this is the first case report containing a detailed description of oral symptoms and supporting photographs.

In our patient, the allergic symptoms appeared not only in the oropharynx but also in the abdomen. However, consuming cooked radish did not induce any symptoms. Therefore, this was classified as a class II food allergy. Mustard, which belongs to the same Brassica family as radish, reportedly cross-reacts with mugwort [12]. However, RIST investigations were negative, including those for mugwort, and the sensitizing allergen could not be detected.

Ausukua et al. mentioned "viral infections (herpetic)" as a differential diagnosis for OAS [13]. In our case, we initially suspected herpetic gingivostomatitis because of fever, general malaise, and findings of the oral mucosa. Vegetables of the Brassica family, such as radish, mustard, and wasabi, contain a volatile substance called isothiocyanate, a component that gives them their spicy taste. Glucosinolate is a precursor of isothiocyanate. While glucosinolate itself is not volatile, it chemically reacts with an enzyme called myrosinase that is released after the plant cells are ruptured, yielding isothiocyanate [14]. While the prick test result using grated raw radish was positive for our patient, that of the test using non-grated radish was negative. Grating raw radish destroys cells, causing glucosinolate and myrosinase to chemically react with each other over a sufficient period to form isothiocyanate. It was speculated that the non-grated raw radish did not contain enough isothiocyanate to induce allergy. Thus, isothiocyanate was considered an allergen in our case.

OAS can be prevented by avoiding ingestion of foods containing culprit allergens. In addition, consuming antihistaminic drugs before ingestion of the causative food may alleviate symptoms [4]. In our case, antihistamine and injectable epinephrine were prescribed prophylactically to help the patient control any accidental onset in the future.

OAS can be readily diagnosed if the causative food is identified. However, guiding the diagnosis can be challenging unless the patient is aware of food allergies. When encountering widespread erosion in the oral cavity, it is essential to keep OAS in mind.

\section{Abbreviations}

OAS: Oral allergy syndrome

RAST: Radioallergosorbent test

RIST: Radioimmunosorbent test

\section{Declarations}

\section{Ethic approval and consent to participate.}

Not applicable.

\section{Consent for publication}

Consent for publication was obtained from the patient.

\section{Competing interests}

The authors declare no competing interest in association with the present study.

\section{Funding}

Not applicable. 


\section{Authors' contributions}

$\mathrm{AU}$ and TF were the patient's oral and maxillofacial surgeons, reviewed the literature and contributed to manuscript drafting; MY, and HH were the patient's oral and maxillofacial surgeons, reviewed the literature and drafted the manuscript; all authors issued final approval for the version to be submitted.

\section{Acknowledgments:}

We would like to thank Editage (www.editage.com) for English language editing.

\section{Availability of data and materials}

The dataset supporting the conclusions of this article are included within the article.

\section{References}

1. Amlot PL, Kemeny DM, Zachary C, Parkes P, Lessof MH. Oral allergy syndrome (OAS): symptoms of IgE-mediated hypersensitivity to foods. Clin Allergy. 1987; 17:33-42.

2. Kondo Y, Urisu A. Oral allergy syndrome. Allergol Int. 2009;58:485-91.

3. Ebisawa M, Ito K, Fujisawa T, Committee for Japanese Pediatric Guideline for Food Allergy, The Japanese Society of Pediatric Allergy and Clinical Immunology, Japanese Society of Allergology. Japanese guidelines for food allergy 2020. Allergol Int. 2020;69:370-86.

4. Muluk NB, Cingi C. Oral allergy syndrome. Am J Rhinol Allergy. 2018;32:27-30.

5. Mitchell JC, Jordan WP. Allergic contact dermatitis from the radish, Raphanus sativus. Br J Dermatol. 1974;91:183-9.

6. el Sayed F, Manzur F, Marguery MC, Bayle P, Bazex J. Urticarial manifestations due to Raphanus niger. Contact Dermatitis. 1995;32:241.

7. Sousa N, Gaspar A, Morais-Almeida M. Anaphylaxis to Raphanus niger. Allergy. 2010;65:1202.

8. Damiani E, Aloia AM, Priore MG, Nardulli S, Ferrannini A. Generalized urticaria after ingestion of Raphanus sativus. Ann Allergy Asthma Immunol. 2011;106:168.

9. Kirisawa T, Moriya Y, Matsumoto S, Morioka K. A case of widespread allergic contact stomatitis caused by grated Japanese radish [article in Japanese]. Jpn J Oral Maxillofac Surg. 2013;59:598-602.

10. Lee YH, Lee JH, Kang HR, Ha JH, Lee BH, Kim SH. A case of anaphylaxis induced by contact with young radish (Raphanus sativus L). Allergy Asthma Immunol Res 2015;7:95-97.

11. Abe S, Ito J, Harada S, Sasano H, Ueda S, Sandhu Y, et al. A case of hand urticaria, lip angioedema, and oropharyngeal pruritus induced by Japanese radish through IgE-mediated immediate allergic reaction. Allergy Asthma Clin Immunol. 2021;17:36.

12. Figueroa J, Blanco C, Dumpiérrez AG, Almeida L, Ortega N, Castillo R, et al. Mustard allergy confirmed by double-blind placebo-controlled food challenges: clinical features and cross-reactivity with mugwort pollen and plant-derived foods. Allergy. 2005;60:48-55.

13. Ausukua M, Dublin I, Echebarria MA, Aguirre JM. Oral allergy syndrome (OAS). General and stomatological aspects. Med Oral Patol Oral Cir Bucal. 2009;14:e568-e572.

14. Holst B, Williamson G. A critical review of the bioavailability of glucosinolates and related compounds. Nat Prod Rep. 2004;21:425-47.

\section{Tables}

Table 1. Results of the radio immunosorbent test (RIST) and radioallegrosorbent test (RAST) 


\begin{tabular}{|c|c|c|c|}
\hline Radioimmunosorbent test & & Radioallergosorbent test & \\
\hline \multirow[t]{17}{*}{ Total IgE amount in serum } & $35.0 \mathrm{IU} / \mathrm{mL}$ & Birch & Negative \\
\hline & & Vernal grass & Negative \\
\hline & & Dactylis & Negative \\
\hline & & Ragweed & Negative \\
\hline & & Mugwort & Negative \\
\hline & & Cedar & Negative \\
\hline & & Cypress & Negative \\
\hline & & Cat dander & Negative \\
\hline & & Dog dander & Negative \\
\hline & & Candida albicans & Negative \\
\hline & & House dust mite & Negative \\
\hline & & House dust & Negative \\
\hline & & Mackerel & Negative \\
\hline & & Horse-mackerel & Negative \\
\hline & & Anisakis & Negative \\
\hline & & Latex & Negative \\
\hline & & Hev b 6.02 (Latex-derived) & Negative \\
\hline
\end{tabular}

Table 2. Clinical characteristics of 8 patients with radish allergy

\begin{tabular}{|c|c|c|c|c|c|c|c|c|c|c|}
\hline & Year & Reference & Age & Gender & $\begin{array}{l}\text { Cooking } \\
\text { form }\end{array}$ & $\begin{array}{l}\text { Oral } \\
\text { symptoms }\end{array}$ & Extraoral symptoms & $\begin{array}{l}\text { Other } \\
\text { allergies }\end{array}$ & $\begin{array}{l}\text { Skin } \\
\text { prick } \\
\text { test }\end{array}$ & $\begin{array}{l}\text { Allergic } \\
\text { reaction } \\
\text { due to } \\
\text { heating }\end{array}$ \\
\hline 1 & 1974 & $\begin{array}{l}\text { Mitchell } \\
\text { et al. (5) }\end{array}$ & 38 & $\mathrm{~F}$ & Salad & $\mathrm{Nc}$ & Dermatitis of hand & $\mathrm{Nc}$ & NC & NC \\
\hline 2 & 1995 & $\begin{array}{l}\text { Sayed et } \\
\text { al. (6) }\end{array}$ & 16 & $\mathrm{~F}$ & $\begin{array}{l}\text { Food } \\
\text { supplement }\end{array}$ & Nc & Urticaria of the trunk and arm & Nc & Positive & NC \\
\hline 3 & 2010 & $\begin{array}{l}\text { Sousa et } \\
\text { al. (7) }\end{array}$ & 56 & $\mathrm{~F}$ & $\begin{array}{l}\text { Food } \\
\text { supplement }\end{array}$ & Nc & $\begin{array}{l}\text { Urticaria, facial angioedema, } \\
\text { bronchospasm } \Rightarrow \text { Anaphylaxis }\end{array}$ & $\begin{array}{l}\text { Allergic } \\
\text { rhinitis }\end{array}$ & Positive & NC \\
\hline 4 & 2011 & $\begin{array}{l}\text { Damiani } \\
\text { et al. (8) }\end{array}$ & 66 & $\mathrm{~F}$ & Salad & Nc & $\begin{array}{l}\text { Generalized urticaria, mild } \\
\text { throat tightness }\end{array}$ & Nc & Positive & NC \\
\hline 5 & 2013 & $\begin{array}{l}\text { Kirisawa } \\
\text { et al. (9) }\end{array}$ & 39 & $\mathrm{~F}$ & Grated & Stomatitis & None & $\begin{array}{l}\text { Not } \\
\text { detected }\end{array}$ & NC & Negative \\
\hline 6 & 2015 & $\begin{array}{l}\text { Lee et } \\
\text { al. (10) }\end{array}$ & 46 & $\mathrm{~F}$ & Pickles & Nc & $\begin{array}{l}\text { Dizziness, generalized } \\
\text { eruption, gastrointestinal } \\
\text { upset } \Rightarrow \text { Anaphylaxis }\end{array}$ & Metal & Positive & NC \\
\hline 7 & 2021 & $\begin{array}{l}\text { Abe et al. } \\
(11)\end{array}$ & 48 & $\mathrm{~F}$ & Grated & $\begin{array}{l}\text { Lip } \\
\text { angioedema, } \\
\text { oropharyngeal } \\
\text { pruritus }\end{array}$ & Urticaria of hand & $\begin{array}{l}\text { House } \\
\text { dust } \\
\text { mite, } \\
\text { cedar } \\
\text { pollen }\end{array}$ & Positive & Negative \\
\hline 8 & 2021 & $\begin{array}{l}\text { Present } \\
\text { case }\end{array}$ & 31 & M & Grated & Stomatitis & $\begin{array}{l}\text { General malaise, abdominal } \\
\text { pains }\end{array}$ & $\begin{array}{l}\text { Not } \\
\text { detected }\end{array}$ & Positive & Negative \\
\hline
\end{tabular}

\section{NC, No Comment; F, Female; M, Male}

Figures 

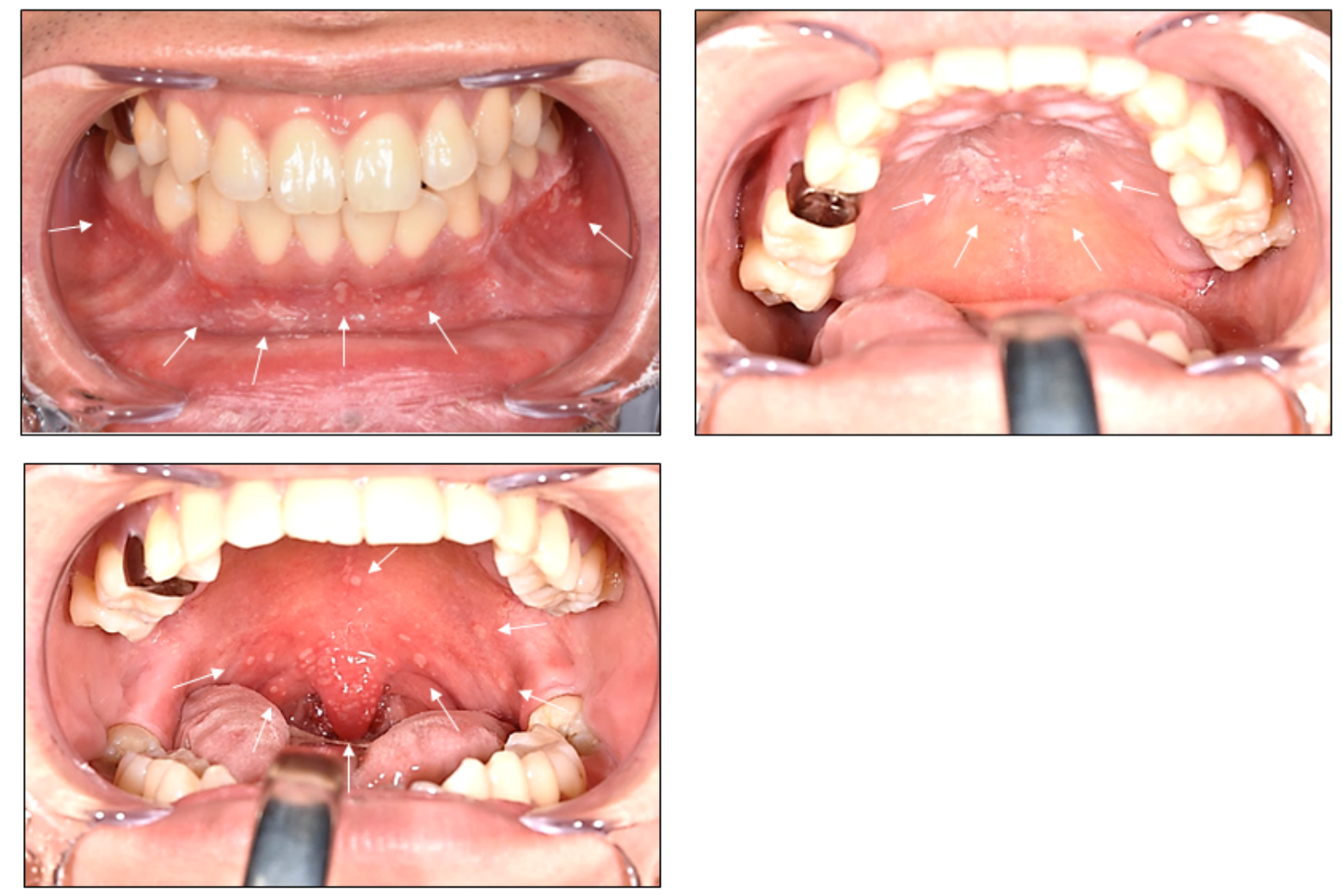

Figure 1

Oral findings at first visit 

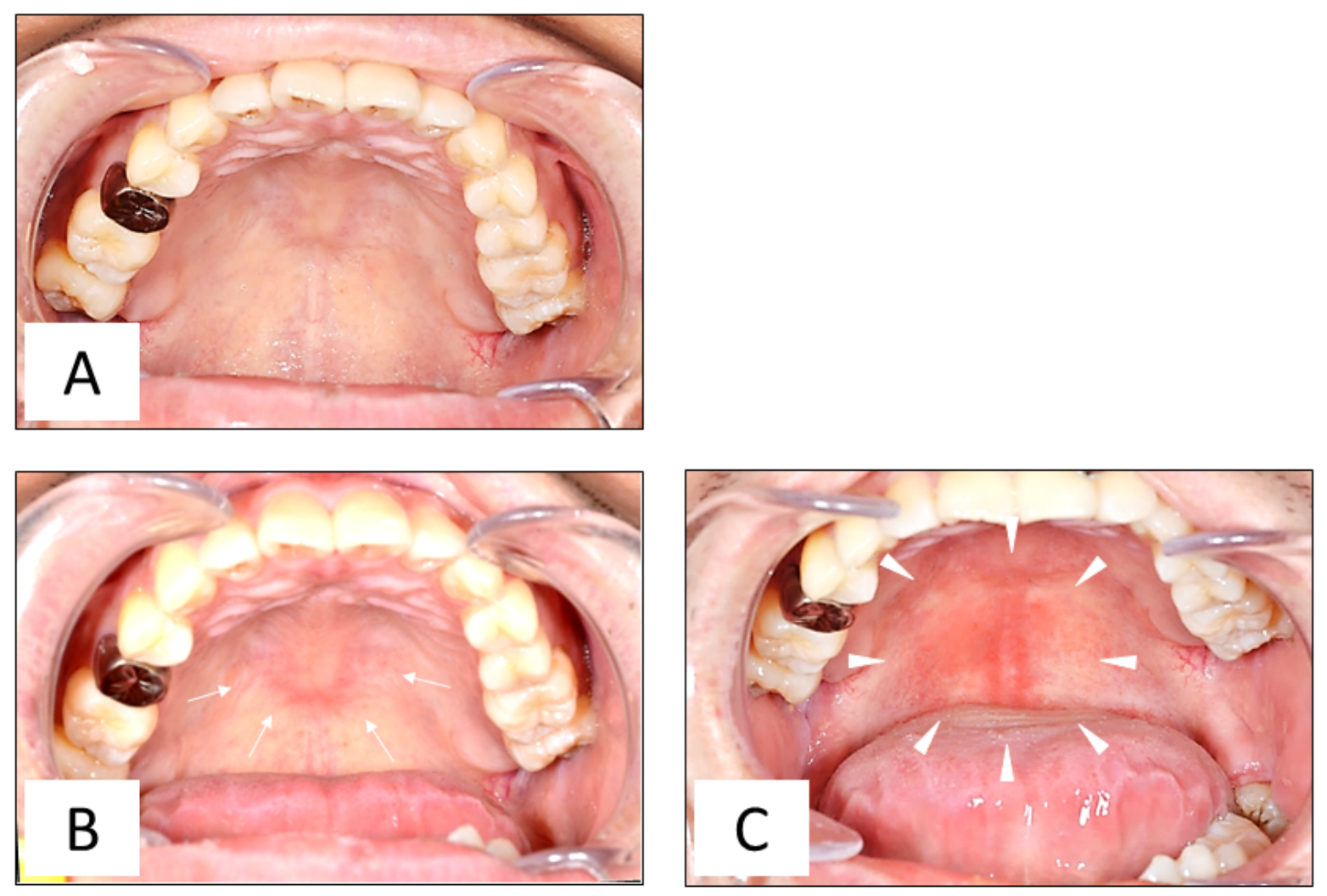

Figure 2

Oral findings at the time of the oral challenge test

\section{Supplementary Files}

This is a list of supplementary files associated with this preprint. Click to download.

- 2010Allergy.pdf 